粘液産生膵腫瘍の良性悪性の鑑別についての検討

千葉大学第 2 外科

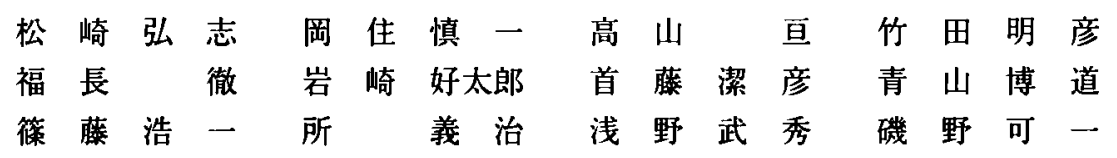

粘液産生愺腫瘍の衰胞径・乳頭状隆起の有無による良悪性の鑑別について検討した。 標本における敦胞径は良性群で $20.2 \pm 7.7 \mathrm{~mm}$ (mean $\pm \mathrm{SD}$ ), 悪性群で $28.7 \pm 8.8 \mathrm{~mm}$ と, 悪性例で有意に大きかった，乳頭状隆起を有する割合は熏性群で高く，隆起径も大きい 傾向にあったが，有意差は認めなかった，䡛胞径が $20 \mathrm{~mm}$ 以下で乳頭状隆起を認めな かった 8 例のうち，良性が 7 例 $87.5 \%$ を占め，襄胞径 $20 \mathrm{~mm}$ を超えるかまたは乳頭状隆 起を認めた 21 例のうち, 16 例 $76.2 \%$ が悪性であった. 画像診断においては, 表胞の描出 は比較的優れていたが，乳頭状隆起の描出については不良であった。画像上咅胞径 20 $\mathrm{mm}$ 以下で乳頭状隆起が描出されない症例を良性と判定したときの正診率は $71.4 \%$ で あり，乳頭状隆起の描出能の向上と，他の方法を組み合わせたさらに多角的な診断法が 今後必要と考えられた。

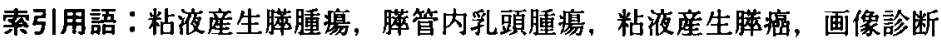

\section{緒言}

粘液産生莝腫瘍は 1982 年大檑ら”により提唱された 疾患概念であり，最近の診断技術の進歩に伴い報告例 が增加している"．本疾患は一般に通常型膁㾋に比し て子後良好といわれているが，中には膁実質や他臟器 への浸潤を認め，予後不良な症例も報告されるように なってきており，治療方針に迷うことも少なくな い:131. 今回われわれは教室で経験した粘液産生脯腫湯 29 例について画像診断による良悪性の鑑別の可能性 について検討を行ったので，若干の文献的考察を加え 報告する。

\section{対象および方法}

对象は 1982 年 11 月〜1997年 1 月までに教室で経 験した粘液産生滕腫堭切除例 29 例（悪性 17 例，良性 12 例) である。年齢は $60 \pm 10$ 歳（mean $\pm S D ） ，$ 男性 19 例，女性 10 例であった. 全て黑田"の臨床病理学的 分類におけるI型 (腪管内腺腫・癌)に相当する症例で あり, 主膵管型 7 例 (全て悪性)，分枝轮管型 22 例 (悪 性 10 例) であった。

まず，手術標本において丵胞径・乳頭状隆起の有無

1998 年 3 月 24 日受付 1998 年 11 月 18 日探用
と良悪性との関係について検討した。次にこれをもと に画像診断による良悪性の爁別の可能性について検討 を加えた，術前の検査法別に曹胞径および乳頭状隆起 の描出能を検討し，これらを組み合わせた良悪性の正 診率を算出した，衰胞径については US, CT, ERP，乳頭 状隆起についてはUS.CT, EUS，愺管鏡を用いた。

なお，有意差検定には $\mathrm{t}$ 検定を用いた。

\section{結果}

A. 手術標本における裹胞径・乳頭状隆起の有無と 良悪性

標本において肉眼的に糔胞を認めた 23 例において， 裹胞径と良悪性について検討すると，蒦胞径は良性群 で $20.2 \pm 7.7 \mathrm{~mm}$ (mean $\pm \mathrm{SD}$ ), 悪性群で $28.7 \pm 8.8 \mathrm{~mm}$ と，悪性群で有意に大きかった $(\mathrm{p}<0.05$ )（图 1)，また， 乳頭状隆起の有無と良悪性について検討すると，標本 上隆起を認めた症例は良性群で 12 例中 3 例 $(25 \%)$ ， 悪性群で 17 例中 12 例 $(70.6 \%)$ と悪性群において多 かった，隆起を有する症例において，隆起径は良性群 で $6.3 \pm 4.0 \mathrm{~mm}$ (mean $\pm \mathrm{SD})$ ，悪性群で $15.0 \pm 7.7 \mathrm{~mm}$ と悪性群で大きい傾向にあった（表 1)。

次に，莗胞径および乳頭状隆起と良悪性について検 討した．襄胞径が $20 \mathrm{~mm}$ 以下で乳頭状隆起を認めな 


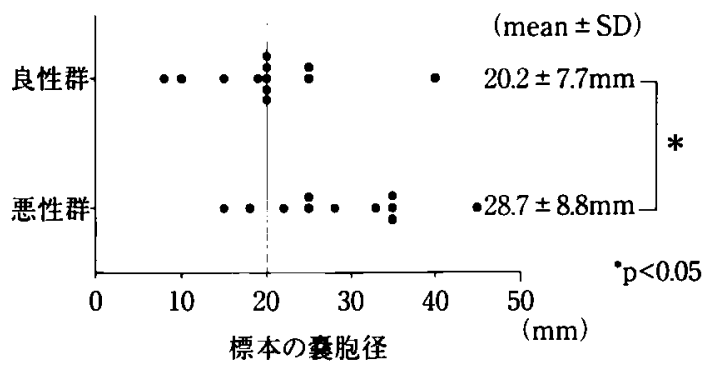

图 1 豆胞径と良悪性

かった 8 例のうち，良性が 7 例 $87.5 \%$ を占めた.また， 烡胞径 $20 \mathrm{~mm}$ を超えるかまたは乳頭状隆起を認めた 21 例のうち，16 例 $76.2 \%$ が悪性であった（表 2).

B. 画像診断に上る術前の良悪性の䑤別

上記の結果をふまえ, 29 例中術前の画像診断につい て検討し得た 28 例につき, 術前の画像上胞怪 20 $\mathrm{mm}$ 以下で乳頭状隆起が描出されない症例を良性と判 定したとき，正診が可能かどうかを検討した。

まず, 術前の検査法別に裹胞径の描出能について検 討すると, 標本の裹胞径と描出された咅胞径との相関 はCT,USで高く，ERPではやや不良であったが（図 2)，各検查法を組み合わせることにより，2 cm を超え る烡胞の正診率は $95.5 \%$ と良好であった。

また，乳頭状隆起の描出能について検討した(表 3). US は 28 例に施行し, 標本上隆起を有した 14 例中 5 例で隆起 $(+)$ と判定, 隆起を有さなかった 14 例中 13 例で隆起 (一) と判定した，同様に，CT は 25 例に施 行し，その内 3 例に隆起 (+)を，10 例に隆起 (-)を 正診しえた.EUSは 10 例中 8 例，脑管鏡は 19 例中 11 例を正診し得た．以上より，隆起の有無の正診率はそ れぞれUSで $64.3 \%$ ，CT で $52.0 \%$, EUS で $80.0 \%$ ，腪 管鏡で $57.9 \%$ であった. EUS は例数が 10 例と少ない ものの，主羘管および副膵管，分枝の全ての領域で隆 起の描出が可能であった。粗管鏡では 9 例中 6 例で隆 起を描出できなかったが，そのうち 3 例が分枝病変, 1 例が副膵管内の病変であった。

以上をふまえ, 各画像診断中最大に描出された表胞 径が $20 \mathrm{~mm}$ を超えるか, または隆起が描出された症例 を悪性，それ以外を良性と判定したとき，組織学的な 良悪性と一致したのは 28 例中 20 例であり, 術前画像 診断の正診率は $71.4 \%$ であった (表 4)，偽陰性 4 例の 内訳は, 標本上も共胞径 $20 \mathrm{~mm}$ 以下で隆起 (ー) だっ た 2 例のほかは，主朠管の隆起を画像診断で描出でき なかった 2 例であった。また，偽陽性 4 例の内訳は，
表 1 乳頭状隆起と良悪性

\begin{tabular}{|c|c|c|c|c|}
\hline & 隆起 (一) & 隆起 (+) & $\begin{array}{c}\text { 隆起往 } \\
\text { mean } \\
=\mathrm{SD}\end{array}$ & \\
\hline 良性群 & 9 (例) & 3 & $\begin{array}{c}6.3 \pm 4.0 \\
(\mathrm{~mm})\end{array}$ & \multirow{2}{*}{ NS } \\
\hline 畽性群 & 5 & 12 & $15.0 \pm 7.7$ & \\
\hline
\end{tabular}

表 2 夏胞徍および乳頭状隆起と良悪性

\begin{tabular}{|c|c|c|}
\hline & $\begin{array}{l}\text { 㬴胞径 } \\
\quad \leqq 20 \mathrm{~mm}\end{array}$ & $20 \mathrm{~mm}<$ \\
\hline 隆起 (-) & $\underset{x}{0000000}$ & ${ }_{x \times x \times x}^{O 0}$ \\
\hline 隆起 (+) & $\mathrm{O}_{x \times \times \times x}$ & ${ }_{x \times x \times x}^{0}$ \\
\hline \multicolumn{2}{|c|}{$\begin{array}{l}\square \text { 良性 } 87.5 \%(7 / 8) \\
\square \text { 悪性 } 76.2 \%(16 / 21)\end{array}$} & $\begin{array}{l}\mathrm{O} \text { : 良性 } \\
\times \text { ：整性 }\end{array}$ \\
\hline
\end{tabular}

羘管鏡でいくら状所見を認めたが，標本では平滑で あった 1 例の他は，標本上も隆起または $20 \mathrm{~mm}$ を超え る襄胞を有した 3 例であった。

\section{考 察}

粘液産生蒂腫瘍は 1980 年大橋らにより報告された 特街的な腣癌が最初の報告例とされ，1982 年 “粘液産 生䐙癌"として初めて提唱された疾患概念である゙，と ころが，巨房型粘液性咅胞腺腫（腺癌）をこれに含め るか等，定義に混乱がみられたため，柳澤らは「臨床 的には主膵管の粘液貯留による抎張と乳頭口開大など の特異的な垷候を示すことを特徽（必要条件）とし， かつ, 病理学的には羘管内に羘管上皮乳頭增殖がみら

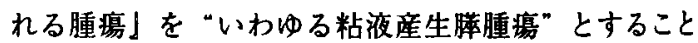
を提唱し ${ }^{6}$ ，概ね合意が得られている.これは黒田の陁 床病理学的分類におけるI 型（脺管内腺腫・癌)”に相 当し，われわれは 1982 年 11 月〜 1997 年 1 月までにこ の範疇に属すると考えられる膀腫瘍を 29 例経験した。 本疾患は報告例の蓄積により, 組織学的に良性腫㿋 が含まれることが判明し，また悪性例も一般には通常

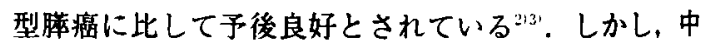
には間質浸潤例，再発死亡例が散見されており，術前 よりの良悪性の判定，さらに癌の症例における悪性度 の判定が治療方針の決定に重要である.

今回の検討で，手術標本に扔ける裹胞径が $2 \mathrm{~cm}$ 以 下で乳頭状隆起を伴わない症例は $87.5 \%$ が良性であ り，これらの中には年齢その他の要素を考虑すれば, 手術せずに follow up してもよい症例も含まれると考 えられた。これ以外のものは良悪性が混在しており现 


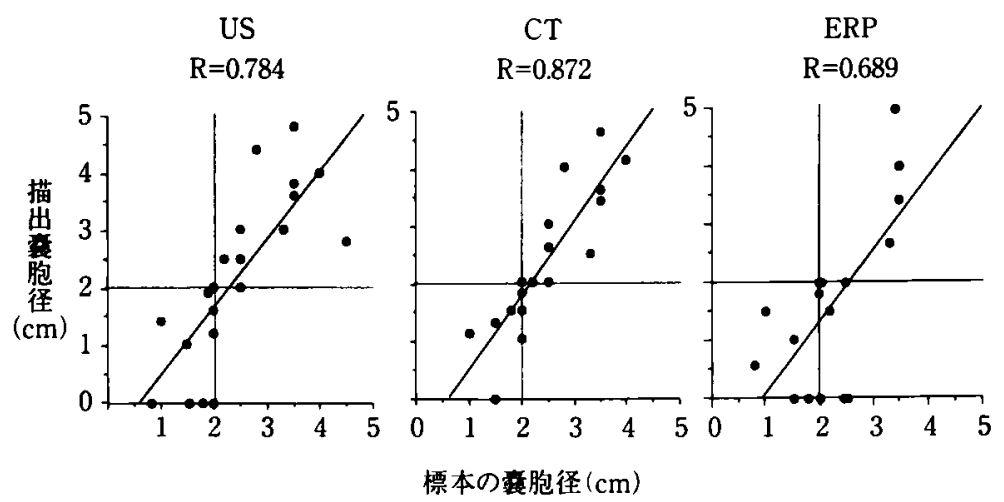

图 2 検查法別夏胞径の描出能

表 3 検査法別乳頭状隆起の描出能

\begin{tabular}{|c|c|c|c|c|c|c|c|c|}
\hline & \multicolumn{2}{|c|}{ US } & \multicolumn{2}{|c|}{ CT } & \multicolumn{2}{|c|}{ EUS } & \multicolumn{2}{|c|}{ 羘管鏡 } \\
\hline & $(+)$ & $(-)$ & $(+)$ & $(-)$ & $(+)$ & $(-)$ & $(+)$ & $(-)$ \\
\hline $\begin{array}{l}\text { 標本で } \\
\text { 隆起(+) }\end{array}$ & $\begin{array}{c}5 \\
\text { (例) }\end{array}$ & 9 & 3 & 10 & 6 & 0 & 3 & 6 \\
\hline 隆起(一) & 1 & 13 & 2 & 10 & 2 & 2 & 2 & 8 \\
\hline 正診率 & \multicolumn{2}{|c|}{$64.3 \%$} & \multicolumn{2}{|c|}{$52.0 \%$} & \multicolumn{2}{|c|}{$80.0 \%$} & \multicolumn{2}{|c|}{$57.9^{\circ}}$, \\
\hline
\end{tabular}

時点では基本的に手術適応と考えている。いずれにせ よ形態学的には clear cut な良悪性の鑑別は困難で あった，諸施設の報告でも，主羘管径や莀胞径の大き い症例，隆起性病変を認める症例は悪性度が高いとす る報告が多いい方。また，主䐙管型は分枝型に比して 悪性例が多いとする報告も複数みられ ${ }^{101111}$ ，教室の症 例においても癌の占める割合は主膵管型で 100\%（7/ 7）と，分枝型で $45.5 \%$ (10/22) であった.

萁胞径と隆起を用いた画像診断による良悪性の鑑別 の可能性についても検討した．軍胞径の描出は各画像 診断で良好であったが, 乳頭状隆起の描出は 50 83.3 \%とばらつきがみられた. US, CT, EUS, 膡管鏡の 4 つ の手段のうち, US は検者の技量に左右される上，患者 の体格消化管のガス等のさまざまな影響を受けやす く，体外からの膵臓の観察では常に安定した診断をす るのは困難である.また，数 $\mathrm{mm}$ から $1 \mathrm{~cm}$ 前後の隆起 の描出を目的とするには，US、CT ともに現行の機器の 空間分解能では限界がある.羘管鏡は主䐙管の病変を 直梘するには有利だが，分枝病変や副膦管内の病変を 安定して観察し得るとは限らない. 現時点でEUSはこ れらの欠点を比較的カバーしており，莗胞壁の厚さや 隆起についての EUSによる診断に関しては諸家の報
表 4 戛胞徍・釈頭状隆起からみた術前画像診断の正診率

\begin{tabular}{|c|c|c|}
\hline & 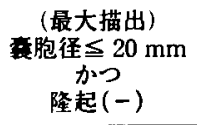 & $\begin{array}{c}20 \mathrm{~mm}<\text { 賈胞径 } \\
\text { まだ } \\
\text { 隆起(+) }\end{array}$ \\
\hline $\begin{array}{c}\text { (組織学的に) } \\
\text { 良性 }\end{array}$ & 8 (例) & 4 \\
\hline 悪性 & 4 & 12 \\
\hline
\end{tabular}

告がみられる゙121. 今回の検討では EUS を施行した症 例数が少なく，偽陽性が 2 例あったが，隆起を有した 6 例全てについて描出可能であり，正診率は 80\%で あった. 分枝病変については, EUSに加え, IDUSを施 行することでさらに描出能が向上するという報告もあ $ろ^{12)}$.

本診断法すなわち，毫胞径と乳頭状隆起からみた術 前画像診断の正診率は $71.4 \%$ と满足すべき値とはい えない. 偽陽性 4 例のうち 3 例，㑶陰性 4 例のうち 2 例 は標本上の隆起の有無または $20 \mathrm{~mm}$ を超える豪胞を 正しく描出し得た症例であり，軎胞径と隆起をもとに したマクロの形態診断の限界ともいえる．他の偽陽性 ・㑶陰性症例は, いずれも隆起の有無を正しく診断出 来ない例であり，EUS・䐙管鏡の技術的・ハード面で の進歩や，IDUS・MRI といった他の画像診断による 描出率の改善が当面の課題と考えられる。

本疾㭧は基本的に low grade malignancy と考えら れており，当科でも原則として櫒機能温存術式帛を 行っている. しかし, 組織学的に通常型膆癌に類似し た脺実質浸潤・神経浸潤を認め，腹膜播種再発した例 を1 例経験している. 今回は検討しえなかったが、こ ういった悪性度の高い症例を術前に拾い上げることも 
重要な課題である．また，良悪性の境界病変を多く含 むという疾患の性格上，形態学的な診断のみでは限界 があることもまた事実であり，遗伝子診断等を含めた 総合的な診断法の確立が今後必要と考えられる.

$$
\text { 結 語 }
$$

粘液産生䐙腫瘍 29 例につき, 豪胞径・乳頭状隆起の 有無による良悪性の籃別について検討した。標本上の

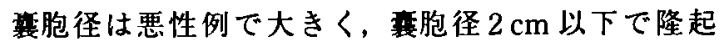
(ー)の症例は $87.5 \%$ が良性であった．画像診断上衰胞 径が $2 \mathrm{~cm}$ 以下で乳頭状隆起 (-) の症例を良性と判定 すると，正診率は $71.4 \%$ であり，隆起の描出能の向上 が今後の課題と考えられた.

なお，本論文の要旨は第 58 回日本臨床外科医学会総会に おいて発表した。

\section{文献}

1）大橋計彦, 村上義史, 丸山雅一他：粘液産生䐙癌の 4 例. Progress of Digestive Endoscopy $20: 348-$ 351,1982

2) Kimura W. Sasahira N, Yoshikawa T, et al : Ductectatic type of mucin producinng tumor of the pancreas - New concept of pancreatic neoplasia-. Hepato-Gastroenterol $43: 692-709,1996$

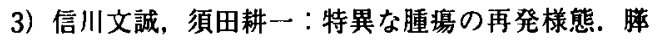
癌一脺管内乳頭腺癌を中心に一. 肝・胆・䐙
$31: 673-677,1995$

4）黒田 彗, 森岡恭彦：粘液産生愺腫瘍. 外科 54 ： $328-335,1989$

5）大橋計彦, 田尻久雄, 権藤守男他：総胆管一愺管瘖 を形成した苏要胞状腺癌の 1 切除例. Progress of Digestive Endoscopy $17: 261-264,1980$

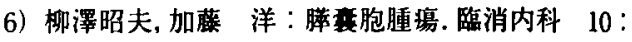
1129-1137, 1995

7）真口宏介：粘液産生羘腫瘍の臨床病理学的および 診断学的研究. 日消病会誌 $91 ： 1003-1015,1994$

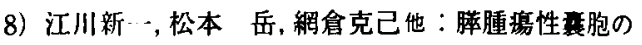
外科治療方針. 消外 $19: 1689-1694,1996$

9）今泉俊秀, 羽鳥 隆, 中迫利明他：粘液産生膵腫瘍 の治療. 消外 $19: 1695-1702,1996$

10）小原 剛, 真口宏介, 浦等他：羘管内乳頭腺

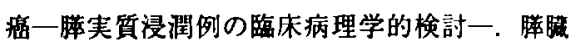
$8: 119-127,1993$

11）田中明隆,伊東和幸, 松井泰道他: 分枝型粘液産生 腫瘍の臨床病理学的検討. 蓃䑏 $10: 368-373$, 1993

12）早川真也, 後藤秀実, 廣岡芳樹他：羘恶胞性疾患の

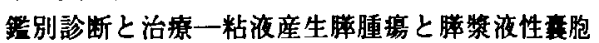
腺腫の診断を中心に. 消外 $19: 1677-1687.1996$

13）高山亘, 竜 崇正, 渡辺一男他：Santorini 系勝 頭部温存膡垔全摘を施行した粘液産生膵癌の1 例. 腆臓 $8: 462-467,1993$

\title{
A STUDY ON THE DIFFERENTIATION BETWEEN BENIGNANCY AND MALIGNANCY OF MUCIN-PRODUCING TUMOR OF THE PANCREAS
}

\author{
Hiroshi MATSUZAKI, Shinichi OKAZUMI, Wataru TAKAYAMA, Akihiko TAKEDA, \\ Toru FUKUNAGA, Kotaro IW ASAKI, Kiyohiko SHUTO. Hiromichi AOY AMA. \\ Koichi SHINOTO, Yoshiharu TOKORO. \\ Takehide ASANO and Kaichi ISONO \\ Department of Surgery II. Chiba University School of Medicine
}

This study dealt with the differentiation between binignancy and malignancy of mucin-producing tumors of the pancreas based on diameter of the cyst and the presence of papillary elevation. The cyst diameters in resected materials were $20.2 \pm 7.7 \mathrm{~mm}$ (mean $\pm \mathrm{SD}$ ) in benign group versus $28.7 \pm 8.8 \mathrm{~mm}$ in malignant group, revealing a significantly greater diameter in the malignant cases. The rate of tumor with papillary elevation was higher in malignant group and diameter of the elevations tended to be greater in the malignant group. without significant difference. Of eight tumors with the cyst diameter of less than $20 \mathrm{~mm}$ without papillary elevation, seven tumors $(87.5 \%$ ) were benign. Among 21 cases which had cyst diameter of more than $20 \mathrm{~mm}$ or papillary elevation, 16 cases $(76.2 \%)$ were diagnosed as malignant. Imaging procedures were comparatively excellent in visualization of the cyst, but poor in visualization of papillary elevation. If the cases in which the cyst diameter was less than $20 \mathrm{~mm}$ and no papillary elevation was visualized were diagnosed as benign, the correct diagnosing rate was $71.4 \%$. It is thought that further improvement in the ability of visualizing the papillary elevation and more multilateral diagnosing procedures combined with other methods are needed. 